\title{
Effect of Agrochemicals Used in the Cultivation of Soybean and Irrigated Rice on Beauveria bassiana (Bals.) Vuill. and Metarhizium anisopliae (Metsch.) Sorok
}

\author{
Vanessa P. Gonçalves ${ }^{1}$, Cândida R. J. de Farias ${ }^{1}$, Victoria Moreira-Nunêz ${ }^{1}$, Renata Moccellin ${ }^{1}$, \\ Viviana Gaviria-Hernández ${ }^{1} \&$ Ana Paula S. A. da Rosa ${ }^{2}$ \\ ${ }^{1}$ Departamento de Fitossanidade Universidade Federal de Pelotas, Capão do Leão, Rio Grande do Sul, Brazil \\ ${ }^{2}$ Embrapa Clima Temperado, Pelotas, Rio Grande do Sul, Brazil \\ Correspondence: Vanessa Pinto Gonçalves, Universidade Federal de Pelotas, Capão do Leão, Rio Grande do Sul, \\ Brazil. Tel: 55-539-8438-6162. E-mail: vanessapg83@hotmail.com
}

Received: November 27, $2018 \quad$ Accepted: July 27, $2019 \quad$ Online Published: October 15, 2019

doi:10.5539/jas.v11n17p167

URL: https://doi.org/10.5539/jas.v11n17p167

\begin{abstract}
The objective of this work was to evaluate the fungitoxic effect of the agrochemicals used in the cultivation of soybean and irrigated rice on entomopathogenic fungi such as Beauveria bassiana and Metarhizium anisopliae by means of the mycelial growth, sporulation and spore germination. The isolates were inoculated in potato-dextrose-agar (PDA) medium containing the pesticides and exposed to spraying with the products. It was observed that chlorantraniliprole produced the best results regarding and was compatible with the two methods of contact of the product with the fungi. Flubendiamide it's very toxic to fungi, producing $100 \%$ inhibition when incorporated into the medium, when by spraying, the fungus M. anisopliae got mycelial growth. Etofenprox and thiamethoxam changed their toxity classification according to the method of contact with product, was moderately compatible to B. bassiana and compatible to $M$. anisopliae and spinosad showed more compatibility with $M$. anisopliae than $B$. bassiana and was classified as compatible. Among fungicides the tricyclazole was the only compatible with the fungus by the spray method. The results showed that in vitro agrochemicals such as tricyclazole, thiamethoxam, flubendiamide and etofenprox are harmful to fungi. It was found that environmental interference could minimize the effects on organisms, especially when the chemicals are applied by spraying.
\end{abstract}

Keywords: entomopathogens, phytosanitary products, toxicity, selectivity

\section{Introduction}

Pest control has been achieved mainly by the use of agrochemicals, the sales of fungicides and insecticides for phytosanitary use increased on average by $12.3 \%$ from 2014 to 2015 , with fungicides having a considerable share, from $10.0 \%$ in 2014 to $17.0 \%$ in 2015 . Insecticides decreased from $21.0 \%$ in 2014 to $17.0 \%$ in 2015 (Sindieveg, 2016). As a consequence of the intensive use of agrochemicals and their unnecessary applications, the number of products resistant pathogens increased as well as toxicity to their natural enemies (Chávez et al., 2016; Reis et al., 2018).

Due to the potential inherent in the control of these insect pests, $M$. anisopliae is the species with the highest number of products registered in MAPA (Agrofit, 2017) and the most commercialized by Brazilian companies, because they produce high values of proteolytic enzymes that degrade the cuticle of their hosts (Bettiol, 2011; Silva et al., 2018).

The fungus B. bassiana is also part of the group of natural pest biocontrollers. It is used to control several insect pests, such as the spider mite Tetranychus urticae Koch, 1836 (Acari: Tetranychidae), the Dactylopius coccus (Costa, 1835) (Hemiptera: Dactylopiidae) the termites Coptotermes spp. (Blattodea: Rhinotermitidae), whitefly Bemisia tabaci (Gennadius, 1889) (Hemiptera: Aleyrodidae) and the sugarcane borer Diatraea saccharalis (Fabricius, 1794) (Lepidoptera: Crambidae) (Dalzoto \& Uhry, 2009; Moro et al., 2011; Svedese et al., 2013).

The use of the fungi B. bassiana and M. anisopliae is based particularly on the high genetic variability, their broad spectrum of hosts and the need of ingestion by the insect pests. Generally, the infection they cause is through germ tube growth and introduction of extracellular proteases on the cuticle of the insect, this 
differentiates them from bacteria and viruses, whose infection occurs only by ingestion (Alves et al., 1998; Paiva-Guimarães et al., 2019).

Due to the importance of these organisms in agriculture, many studies have evaluated the compatibility between phytosanitary products and natural enemies, through selectivity (Barbosa et al., 2009; El-Wakeil et al., 2013). Selectivity is the property which the product presents for controlling the target pest, with the lowest possible impact on the components of the agroecosystem (Fonseca et al., 2015).

In this context, the present study aimed to verify the compatibility of fungicides and insecticides recommended for the cultivation of soybeans and irrigated rice on the entomopathogenic fungi B. bassiana and M. anisopliae.

\section{Materials and Methods}

The experiments were conducted at the Phytopathogenic Seed and Fungi Pathology Laboratory of the Phytosanitary Department, belonging to the Federal University of Pelotas, Pelotas, RS and at the Integrated Pest Management Center of Embrapa Clima Temperado, Pelotas, RS, Brazil.

The B. bassiana isolate was obtained from the collection of the FAEM / UFPel Seed Pathology Laboratory and the M. anisopliae isolate (MaCG168) was obtained from the collection of entomopathogenic fungi from Embrapa rice and soybeans. The isolates were identified from morphological and molecular characteristics from the regions (ITS) and (EF1- $\alpha$ ), (White et al., 1990; Carbone \& Kohn, 1999).

Sequences were analyzed and compared to the GenBank database, where both the ITS and EF1- $\alpha$ sequences showed $95 \%$ and $99 \%$ identity to B. bassiana with GenBank accession numbers KX228572.1 and JQ434752.1, respectively. For M. anisopliae, the ITS and EF1- $\alpha$ sequences presented $95 \%$ and $99 \%$ identity with Genebank accession numbers LC200443.1 and KT360950.1, respectively.

The insecticides and fungicides used are recommended for the cultivation of soybeans and irrigated rice (Agrofit, 2016) (Table 1).

Table 1. Agrochemicals registered for soybean and irrigated rice, used in the selectivity assays (Agrofit)

\begin{tabular}{|c|c|c|c|c|}
\hline Active Ingredient & Chemical group & Cat & Vol. Calda & Dose $\left(\mathrm{ha}^{-1}\right)$ \\
\hline Thiametoxam & Neonicotinoide & I & $100-150 \mathrm{~g} / \mathrm{ha}$ & $100^{*}$ \\
\hline Chlorantraniliprole & Antranilamide & I & $100-200 \mathrm{~L} / \mathrm{ha}$ & $100^{*}$ \\
\hline Flubendiamide & Diamide & I & $200-300 \mathrm{~L} / \mathrm{ha}$ & $200^{*}$ \\
\hline Etofenprox & Diphenyl ether & I & $150 \mathrm{~L} / \mathrm{ha}$ & $150^{*}$ \\
\hline Spinosad & Spinosyn & $\mathrm{I}$ & $100-200 \mathrm{~L} / \mathrm{ha}$ & $100^{*}$ \\
\hline Tricyclazol & Benzothiazole & $\mathrm{F}$ & 200-300 L/ha & $200^{*}$ \\
\hline Trifloxistrobin + Protioconazol & Strobirulin + triazolinthione & $\mathrm{F}$ & $200 \mathrm{~L} / \mathrm{ha}$ & $200^{*}$ \\
\hline Trifloxistrobin + Tebuconazol & Triazole + Strobirulin & $\mathrm{F}$ & $200 \mathrm{~L} / \mathrm{ha}$ & $200^{*}$ \\
\hline Azoxistrobin + Ciproconazol & Strobilurin + triazole & $\mathrm{F}$ & $100-200 \mathrm{~L} / \mathrm{ha}$ & $100^{*}$ \\
\hline
\end{tabular}

Note. ${ }^{*}$ Data obtained in Agrofit (2016). Cat $=$ Category; $\mathrm{I}=$ insecticide and $\mathrm{F}=$ fungicide.

To verify the effect of the pesticides on the entomopathogenic fungi, two bioassays were performed: Bioassay1: pesticides were incorporated into the PDA culture medium (potato, dextrose and agar); and Bioassay 2: spraying of the pesticides under the fungal colonies established in the PDA medium.

The experiment was conducted in a completely randomized design, in a $10 \times 2$ bi-factorial scheme, where factor A was composed of 9 products + control (Table 1) and factor B by 2 contact methods (incorporation and spraying).

The variables whose responses were evaluated in the two bioassays were mycelial growth, sporulation and spore germination, using 10 replicates for the first two variables and four replicates for the third variable, selected at random. 200 experimental units were performed for each fungus tested, 100 for each method, totaling 400 experimental units. The control consisted of the growth of fungi in a PDA medium without pesticide (incorporated) and sprayed with water (spraying).

Bioassay 1: Based on incorporation into the culture medium, the doses of the pesticides were added to $400 \mathrm{~mL}$ of the PDA culture medium at $45^{\circ} \mathrm{C}$, not yet solidified. After homogenization, $10 \mathrm{~mL}$ of the medium was poured into $8.5 \mathrm{~cm}$ diameter Petri dishes, and the fungus was then inoculated in the center of each plate by using 
platinum needle from colonies with seven days of mycelial growth. Afterwards, they were kept in the incubation room at $25 \pm 1{ }^{\circ} \mathrm{C}$, and observed a $12 \mathrm{~h}$ photoperiod.

Bioassay 2: During contact by spraying, the fungi were placed in $8.5 \mathrm{~cm}$ diameter Petri dishes containing PDA medium and incubated under the same condition as Bioassay 1, however for four days of growth of the fungus for further spraying under them.

Afterwards, the products were subjected to spraying under the plates (Table 1) using Potter's Tower (Burkard Scientific Uxbridge, UK) calibrated at a pressure of $10 \mathrm{lb} \mathrm{pol}^{-2}$, resulting in a volume of $0.166 \pm 2.61 \mathrm{mg} \mathrm{cm}^{-2}$, using $1 \mathrm{~mL}$ of pesticides per application. Subsequently, the plates were incubated at around room temperature $\left(25^{\circ} \mathrm{C}+1\right)$, with photoperiod of $12 \mathrm{~h}$.

For mycelial growth the colonies were measured daily, with the aid of a digital caliper, until the tenth day. The measurement was performed in two transverse directions of the plate, in order to determine the average diameter of the colonies.

The evaluation of sporulation was carried out on the fifteenth day of incubation, was removed by means of a cutter ( $7 \mathrm{~mm}$ diameter), 5 discs of mycelium of the colonies submitted to the treatments. Disks were added in test tubes containing $20 \mathrm{~mL}$ sterile distilled water with one drop of Tween $80(0.1 \%)$ (dispersant). So the tubes were shaken for one minute in vortex, with subsequent quantification of the conidia by counting in a Neubauer chamber.

To evaluate the viability of the conidia, a mycelial disc was cut through a cutter ( $7 \mathrm{~mm}$ diameter) on the fifteenth day of incubation, the discs were added in test tubes with $10 \mathrm{~mL}$ of sterile distilled water with a drop of Tween $80(0.1 \%)$. Subsequently, a $3 \mu \mathrm{l}$ aliquot of the suspension was deposited on a block of solidified PDA culture medium $\left(0.5 \mathrm{~cm}^{2}\right)$, for germination of the conidia, where they were incubated for $20 \mathrm{~h}$ at a temperature of $25{ }^{\circ} \mathrm{C}$ and 12-h light photoperiod. After the incubation period, the number of germinated conidia was counted using an optical microscope with a 400 -fold increase, a total of 300 conidia were observed randomly at three points in the culture medium block solidified with the conidial suspension (each point 100 conidia were observed), counting the number of germinated and non-germinated conidia.

To determine the toxic effect of pesticides on entomopathogenic fungi, the biological index (IB) was calculated using the formula described by Rossi-Zalaf et al. (2008).

$$
\mathrm{IB}=\frac{47[\mathrm{CV}]+43[\mathrm{ESP}]+10[\mathrm{GER}]}{100}
$$

where, IB = Biological index; CV: Percentage of vegetative growth of the colony after 15 days, in relation to the control; ESP: Percentage of sporulation after 15 days, relative to the control; GER: Percentage of germination of conidia after $20 \mathrm{~h}$, relative to the control.

Based on the values obtained from IB, the toxicological classification of pesticides was obtained, according to the scale described by Rossi-Zalaf et al. (2008): from 0 to 41-toxic; 42 to 66-moderately compatible; > 66-compatible.

The responses to variables, mycelial growth and sporulation were compared by means of the Duncan test at $5 \%$ probability for comparison between the treatments, and the Student's T-test at 5\% probability for comparison between the contact methods of agrochemicals with fungi.

\section{Results and Discussion}

Regarding the compatibility of insecticides with B. bassiana, it was verified that the variable mycelial growth response (CM) differed from the control for all treatments, except the chlorantraniliprole treatment which did not differ significantly. This effect was observed in the two contact forms of the product incorporated into the PDA culture medium and by spraying (Table 1), indicating that the application of the insecticide chlorantraniliprole did not affect the fungus. On the other hand, for chlorantraniliprole, the sporulation rate differed from the control and recorded a reduction of $47.0 \%$ in the incorporation method and $53.0 \%$ by the spraying method. A higher sporulation rate was observed for spinosad when it was incorporated into the medium, spraying produced significantly different results for all treatments in relation to the control. Regarding the biological index (IB), regardless of the mode of contact of insecticides with B. bassiana, flubendiamide was considered toxic according to the scale used, while chlorantraniliprole was considered compatible with the development of the entomopathogenic fungus (Table 4).

The insecticide spinosad reduced the mycelial growth of the entomopathogen; however, it did not significantly reduce the sporulation rate by the incorporation method. On the other hand, in the spray method, a significant 
decrease occurred in both analyzed variables, which resulted in a decrease of $10.31 \mathrm{~mm}$ in the diameter of the colonies and $87.49 \%$ in the sporulation rate. In the spray method, the decrease in sporulation rate caused a change in the classification of the product from compatible when incorporated into the medium to very toxic, a condition that is similar to spraying the product to the field (Table 4).

In an in vitro experiment, conducted by Thilagam et al. (2010) to assess the compatibility of different doses of flubendiamide to $B$. bassiana, a significant inhibition of fungal growth at all doses tested was observed.

In relation to the insecticide thiamethoxam, an inhibition was observed in the development of B. bassiana, with a reduction of mycelial growth by $11.25 \mathrm{~mm}$ and a reduction in sporulation rate by $64.7 \%$. In the incorporation method, there was a $9.61 \mathrm{~mm}$ decrease in mycelial growth and $57.18 \%$ decrease in sporulation in the spray method, compared to the control (Table 2). This shows that it is moderately compatible with the biological index (Table 4). Neves et al. (2001) analyzed the compatibility of the fungi B. bassiana and M. anisopliae with different insecticides, one of which is thiamethoxam and confirmed a significant reduction in the vegetative growth of $B$. bassiana, in the treatments with acetamiprid and thiamethoxam, at the recommended doses. Fregonesi et al. (2016) verified that thiamethoxam affected B. bassiana isolates, but did not promote significant sporulation, although it reduced the vegetative growth and the product was classified as moderately compatible.

Table 2. Mycelial growth of the colonies $(\mathrm{mm})$ and mean number of conidia per $\mathrm{mL}^{-1}\left(\times 10^{5}\right)$, and percentage of Beauveria bassiana inhibition in the presence of pesticides by incorporation and spraying the entomopathogenic fungus

\begin{tabular}{|c|c|c|c|c|c|c|c|c|}
\hline \multirow{2}{*}{ Treatment I.A. } & \multicolumn{4}{|c|}{ Incorporation } & \multicolumn{4}{|c|}{ Spraying } \\
\hline & \multicolumn{2}{|l|}{$\mathrm{CM}(\mathrm{mm})$} & \multicolumn{2}{|l|}{$\mathrm{ESP} \times 105\left(\mathrm{~mL}^{-1}\right)$} & \multicolumn{2}{|l|}{$\mathrm{CM}(\mathrm{mm})$} & \multicolumn{2}{|c|}{$\mathrm{ESP} \times 105\left(\mathrm{~mL}^{-1}\right)$} \\
\hline \multicolumn{9}{|l|}{ Inseticides } \\
\hline Chlorantraniliprole & $27.37 \pm 2.02$ & $\mathrm{Ab}$ & $273.63 \pm 133.05$ & $\mathrm{BCa}$ & $32.22 \pm 3.95$ & $\mathrm{Aa}$ & $98.25 \pm 74.58$ & $\mathrm{Ba}$ \\
\hline Spinosad & $21.36 \pm 2.00$ & $\mathrm{Ba}$ & $360.63 \pm 82.52$ & $\mathrm{ABa}$ & $21.42 \pm 8.40$ & $\mathrm{Ba}$ & $26.00 \pm 10.54$ & $\mathrm{BCb}$ \\
\hline Etofenprox & $13.72 \pm 1.09$ & $\mathrm{Ca}$ & $173.75 \pm 86.44$ & $\mathrm{Ca}$ & $18.30 \pm 8.10$ & $\mathrm{BCa}$ & $47.13 \pm 18.10$ & $\mathrm{BCb}$ \\
\hline Flubendiamide & $0.00 \pm 0.00$ & $\mathrm{Db}$ & $0.00 \pm 0.00$ & $\mathrm{Da}$ & $11.86 \pm 3.95$ & $\mathrm{Ca}$ & $0.75 \pm 0.64$ & $\mathrm{Ca}$ \\
\hline Thiametoxam & $15.13 \pm 0.75$ & $\mathrm{Cb}$ & $182.37 \pm 78.92$ & $\mathrm{Ca}$ & $22.12 \pm 8.09$ & $\mathrm{Ba}$ & $89.00 \pm 63.45$ & $\mathrm{Ba}$ \\
\hline Control & $26.38 \pm 2.37$ & $\mathrm{Ab}$ & $516.25 \pm 181.53$ & Aa & $31.73 \pm 2.40$ & Aa & $207.87 \pm 49.81$ & $\mathrm{Ab}$ \\
\hline $\mathrm{CV}$ & 23.76 & & 38.44 & & 23.76 & & 38.44 & \\
\hline \multicolumn{9}{|l|}{ Fungicides } \\
\hline Azoxystrobin+ciproconazole & $0.00 \pm 0.00$ & $\mathrm{Ba}$ & $0.00 \pm 0.00$ & $\mathrm{Ba}$ & $0.00 \pm 0.00$ & $\mathrm{Ca}$ & $0.00 \pm 0.00$ & $\mathrm{Ba}$ \\
\hline Protioconazol+trifloxystrobin & $0.00 \pm 0.00$ & $\mathrm{Ba}$ & $0.00 \pm 0.00$ & $\mathrm{Ba}$ & $0.00 \pm 0.00$ & $\mathrm{Ca}$ & $0.00 \pm 0.00$ & $\mathrm{Ba}$ \\
\hline Tebuconazol+trifloxystrobin & $0.00 \pm 0.00$ & $\mathrm{Ba}$ & $0.00 \pm 0.00$ & $\mathrm{Ba}$ & $0.00 \pm 0.00$ & $\mathrm{Ca}$ & $0.00 \pm 0.00$ & $\mathrm{Ba}$ \\
\hline Tricyclazole & $0.00 \pm 0.00$ & $\mathrm{Bb}$ & $0.00 \pm 0.00$ & $\mathrm{Ba}$ & $12.19 \pm 4.15$ & $\mathrm{Ba}$ & $37.87 \pm 34.04$ & $\mathrm{Ba}$ \\
\hline Control & $26.38 \pm 2.37$ & $\mathrm{Ab}$ & $516.25 \pm 181.53$ & Aa & $31.73 \pm 2.40$ & Aa & $207.87 \pm 49.81$ & $\mathrm{Ab}$ \\
\hline $\mathrm{CV}$ & 24.08 & & 37.12 & & 24.08 & & 37.12 & \\
\hline
\end{tabular}

Note. Averages followed by the same capital letter in the column do not differ from each other by the Duncan test $(p>0.05)$, for comparison between active principles, averages followed by the same lowercase letter in the row, do not differ by the Student $\mathrm{T}$ test, for comparison of methods within the same variable, at the $5 \%$ level. $\mathrm{CM}=$ Mycelial growth, $\mathrm{ESP}=$ Spores.

The different results found by the authors cited above and in this work, in relation to the insecticide thiamethoxam, showed that this type of variation can occur naturally. This is because isolates obtained from different origins probably acquire, over time, specific genetic characteristics that distinguish them from others isolated from the same species, where the germination was initiated when the conditions of the medium were favorable for the vegetative growth. However, some strains (lineages) are characterized by being capable of germinating under unfavorable conditions (Carlile et al., 2001).

A significant reduction in mycelial growth and sporulation rate was observed in the two methods used, incorporation in the medium and spraying, $5 \mathrm{~mm}$ in the diameter of the colony and $64.67 \%$ in the sporulation rate and $9.61 \mathrm{~mm}$ and $57 \%$, respectively. When the biological index of this product was evaluated, it was observed that the entomopathogenic fungus $B$. bassiana was moderately compatible to the products of the different methods (Table 4). 
Although insecticides act generally on insects at specific points in their physiology (Botelho \& Monteiro, 2011), the mode of action does not determine which products belonging to these groups are selective to B. bassiana. In similar works, the authors classified etofenprox as very toxic to the fungus (Tamai et al., 2002). Different from the results found in this work, this result led to the consideration of the involvement of other factors such as the secondary sites of action, amount and components of the formulation and ability to change the $\mathrm{pH}$ of the culture medium. What could help to understand this variation, are the two products tested in this work with the same chemical subgroup of diamides, where the active ingredient flubendiamide totally controlled the entomopathogens and chlorantraniliprole had behavior significantly equal to that of the control.

For the fungus $M$. anisopliae, it was verified that the application of the insecticide based on spinosad, did not promote significant difference of mycelial growth in relation to the control, in the two methods tested. The only difference that occurred for sporulation was the $30.70 \%$ reduction in spore production when the product was incorporated in the medium. This result is in agreement with the one obtained by Soares and Monteiro (2011), where they verified that insecticides containing spinosad, did not significantly reduce mycelial growth and sporulation of $M$. anisopleae. Pires et al. (2010), also analyzed the selectivity of spinosad to M. anisopliae isolates, where all the concentrations tested did not alter the diameter of the colonies.

The compatibility of spinosad based products with $M$. anisopliae should be related to the natural origin of the active ingredients, which comes from fermentation carried out by Saccharopolyspora spinosa. Products derived from this active ingredient have low toxicity to mammals and non-target organisms with rapid degradation in the environment (Galm \& Sparks, 2015).

The same occurred for the insecticide chlorantraniliprole, where mycelial growth and sporulation rate did not differ significantly from the control for both methods of contact of the fungus with the product (Table 3 ).

Table 3. Mycelial growth of the colonies $(\mathrm{mm})$ and mean number of conidia per $\mathrm{mL}^{-1}\left(\times 10^{5}\right)$, and percentage of Metarhizium anisopliae inhibition in the presence of pesticides by incorporation and spraying the entomopathogenic fungus

\begin{tabular}{|c|c|c|c|c|c|c|c|c|}
\hline \multirow{2}{*}{ Treatment I.A. } & \multicolumn{4}{|c|}{ Incorporation } & \multicolumn{4}{|c|}{ Spraying } \\
\hline & \multicolumn{2}{|l|}{$\mathrm{CM}(\mathrm{mm})$} & \multicolumn{2}{|c|}{$\mathrm{ESP} \times 105\left(\mathrm{~mL}^{-1}\right)$} & \multicolumn{2}{|l|}{$\overline{\mathrm{CM}}(\mathrm{mm})$} & \multicolumn{2}{|c|}{$\mathrm{ESP} \times 105\left(\mathrm{~mL}^{-1}\right)$} \\
\hline \multicolumn{9}{|l|}{ Inseticides } \\
\hline Chlorantraniliprole & $43.31 \pm 9.38$ & $\mathrm{Aa}$ & $90.75 \pm 12.54$ & $\mathrm{ABa}$ & $43.67 \pm 16.96$ & $\mathrm{ABa}$ & $50.25 \pm 20.60$ & $\mathrm{Ab}$ \\
\hline Spinosad & $47.12 \pm 10.11$ & $\mathrm{Aa}$ & $73.37 \pm 18.39$ & $\mathrm{Ba}$ & $47.44 \pm 8.13$ & $\mathrm{ABa}$ & $40.75 \pm 13.90$ & $\mathrm{Ab}$ \\
\hline Etofenprox & $30.56 \pm 7.65$ & $\mathrm{Bb}$ & $0.13 \pm 0.25$ & $\mathrm{Db}$ & $52.17 \pm 8.88$ & $\mathrm{Aa}$ & $49.75 \pm 21.64$ & Aa \\
\hline Flubendiamide & $0.00 \pm 0.00$ & $\mathrm{Cb}$ & $0.00 \pm 0.00$ & $\mathrm{Db}$ & $34.42 \pm 10.50$ & $\mathrm{Ca}$ & $65.37 \pm 24.42$ & $\mathrm{Aa}$ \\
\hline Thiametoxam & $39.92 \pm 7.34$ & $\mathrm{Aa}$ & $22.87 \pm 7.87$ & $\mathrm{Cb}$ & $34.60 \pm 13.79$ & $\mathrm{BCa}$ & $47.75 \pm 4.09$ & Aa \\
\hline Control & $50.56 \pm 8.49$ & $\mathrm{Aa}$ & $105.87 \pm 24$ & $\mathrm{Aa}$ & $52.30 \pm 4.44$ & $\mathrm{Aa}$ & $69.12 \pm 29.03$ & $\mathrm{Aa}$ \\
\hline $\mathrm{CV}$ & 24.43 & & 34.51 & & 24.43 & & 34.51 & \\
\hline \multicolumn{9}{|l|}{ Fungicides } \\
\hline Azoxystrobin + ciproconazole & $0.00 \pm 0.00$ & $\mathrm{Bb}$ & $0.00 \pm 0.00$ & $\mathrm{Ba}$ & $21.80 \pm 1.89$ & $\mathrm{Ca}$ & $0.00 \pm 0.00$ & $\mathrm{Ba}$ \\
\hline Protioconazol+trifloxystrobin & $0.00 \pm 0.00$ & $\mathrm{Bb}$ & $0.00 \pm 0.00$ & $\mathrm{Ba}$ & $32.66 \pm 15.09$ & $\mathrm{Ba}$ & $0.00 \pm 0.00$ & $\mathrm{Ba}$ \\
\hline Tebuconazol+trifloxystrobin & $0.00 \pm 0.00$ & $\mathrm{Bb}$ & $0.00 \pm 0.00$ & $\mathrm{Ba}$ & $18.09 \pm 2.33$ & $\mathrm{Ca}$ & $0.00 \pm 0.00$ & $\mathrm{Ba}$ \\
\hline Tricyclazole & $0.00 \pm 0.00$ & $\mathrm{Ba}$ & $0.00 \pm 0.00$ & $\mathrm{Bb}$ & $47.58 \pm 5.57$ & $\mathrm{Aa}$ & $48.50 \pm 34.24$ & Aa \\
\hline Control & $50.56 \pm 8.49$ & $\mathrm{Aa}$ & $105.87 \pm 24.00$ & $\mathrm{Aa}$ & $52.30 \pm 4.44$ & $\mathrm{Aa}$ & $69.12 \pm 29.03$ & $\mathrm{Aa}$ \\
\hline $\mathrm{CV}$ & 26.89 & & 28.22 & & 26.89 & & 28.22 & \\
\hline
\end{tabular}

Note. Averages followed by the same capital letter in the column do not differ from each other by the Duncan test $(p>0.05)$, for comparison between active principles, averages followed by the same lowercase letter in the row, do not differ by the Student $\mathrm{T}$ test, for comparison of methods within the same variable, at the $5 \%$ level. $\mathrm{CM}=$ Mycelial growth, $\mathrm{ESP}=$ Spores . 
Table 4. Biological index (IB) of toxicity and classification, among some agrochemicals used in the cultivation of irrigated rice and soybean on the entomopathogen Beauveria bassiana

\begin{tabular}{|c|c|c|c|c|}
\hline \multirow{2}{*}{ Product } & \multicolumn{2}{|c|}{ Incorporation } & \multicolumn{2}{|c|}{ Spraying } \\
\hline & IB & Classification & IB & Classification \\
\hline \multicolumn{5}{|l|}{ Inseticide } \\
\hline Chlorantraniliprole & 93.78 & $\mathrm{C}$ & 93.25 & $\mathrm{C}$ \\
\hline Spinosad & 117.29 & $\mathrm{C}$ & 40.43 & $\mathrm{~T}$ \\
\hline Etofenprox & 63.41 & $\mathrm{MC}$ & 61.07 & $\mathrm{MC}$ \\
\hline Flubendiamide & 3.33 & $\mathrm{~T}$ & 19.00 & $\mathrm{~T}$ \\
\hline Thiametoxam & 45.89 & $\mathrm{MC}$ & 57.08 & $\mathrm{MC}$ \\
\hline \multicolumn{5}{|l|}{ Fungicide } \\
\hline Azoxystrobin + ciproconazole & 0.00 & $\mathrm{~T}$ & 0.00 & $\mathrm{~T}$ \\
\hline Tricyclazole & 0.00 & $\mathrm{~T}$ & 78.20 & $\mathrm{C}$ \\
\hline Trifloxistrobin+proticonazole & 0.00 & $\mathrm{~T}$ & 8.33 & $\mathrm{~T}$ \\
\hline Trifloxistrobin + tebuconazole & 0.00 & $\mathrm{~T}$ & 0.00 & $\mathrm{~T}$ \\
\hline
\end{tabular}

Note. IB values and product classification: 0-41 Toxic (T); 42-66 moderately compatible (MC); > 66 compatible (C), determined according to Rossi-Zalaf et al. (2008).

Compatibility studies performed with chlorantraniliprole insecticides using different doses in relation to the fungus also showed compatibility with the entomopathogen (Sitta et al., 2009), corroborating the results obtained in this experiment. Based on the biological index (IB) (Table 5), it was found that the insecticides spinosad and chlorantraniliprole were compatible with the M. anisopliae isolate, according to the classification determined by Rossi-Zalaf et al. (2008).

Table 5. Biological index (IB) of toxicity and classification, among some agrochemicals used in the cultivation of irrigated rice and soybean on the entomopathogen Metarhizium anisopliae

\begin{tabular}{|c|c|c|c|c|}
\hline \multirow{2}{*}{ Product } & \multicolumn{2}{|c|}{ Incorporation } & \multicolumn{2}{|c|}{ Spraying } \\
\hline & IB & Classification & IB & Classification \\
\hline \multicolumn{5}{|l|}{ Inseticide } \\
\hline Chlorantraniliprole & 85.52 & $\mathrm{C}$ & 97.47 & $\mathrm{C}$ \\
\hline Spinosad & 87.75 & $\mathrm{C}$ & 105.98 & $\mathrm{C}$ \\
\hline Etofenprox & 41.78 & $\mathrm{C}$ & 108.59 & $\mathrm{C}$ \\
\hline Flubendiamide & 33.93 & $\mathrm{~T}$ & 103.42 & $\mathrm{C}$ \\
\hline Thiametoxam & 50.71 & $\mathrm{MC}$ & 88.66 & $\mathrm{C}$ \\
\hline \multicolumn{5}{|l|}{ Fungicide } \\
\hline Azoxystrobin+ciproconazole & 0.00 & $\mathrm{~T}$ & 0.00 & $\mathrm{~T}$ \\
\hline Tricyclazole & 0.00 & $\mathrm{~T}$ & 73.44 & $\mathrm{C}$ \\
\hline Trifloxistrobin+proticonazole & 35.00 & $\mathrm{~T}$ & 35.00 & $\mathrm{~T}$ \\
\hline Trifloxistrobin+tebuconazole & 0.00 & $\mathrm{~T}$ & 0.00 & $\mathrm{~T}$ \\
\hline
\end{tabular}

Note. IB values and product classification: 0-41 Toxic (T); 42-66 moderately compatible (MC); > 66 compatible (C), determined according to Rossi-Zalaf et al. (2008).

Insecticides formulated with etofenprox and flubendiamide inhibited mycelial growth and sporulation rate relative to the control. Both variables analyzed were reduced by the flubendiamide product through the method of insecticide incorporation into the culture medium by $100.0 \%$ but in the spray method, it reduced mycelial growth by only $17.88 \mathrm{~mm}$. Etofenprox reduced mycelial growth by $20 \mathrm{~mm}$ and reduced sporulation rate by almost $100.0 \%$ in the incorporation method, with no significant difference in relation to these variables in the spraying method (Table 5).

According to Ghini and Kimati (2000), insecticides act on the nervous and muscular system of insects, but in fungi, interfere with the cell wall, as a result of their action on the enzyme that converts phosphatidylethanolamine to phosphatidylcholine and inhibits the synthesis of the chitin component of the cell wall of these organisms. 
By using the biological index to evaluate the toxicity of flubendiamide to the microorganism through the incorporation method, it was observed that the fungus takes the active ingredient during its vegetative development to its organism, through the emission of the germinative tube for absorption of nutrients, thus acting directly in its interior, inhibiting it totally or partially being classified as toxic to the fungus.

The insecticide based on thiamethoxam did not reduce mycelial growth in the incorporation method, but there was a reduction in sporulation (78.39\%) when compared to the control. The result was contrary when the colonies of $M$. anisopliae were sprayed.

Based on the biological index (IB) of etofenprox and thiamethoxam, it can be considered that the products were moderately compatible to the fungus by the incorporation method. In the spray method, the toxicological classification showed the compatibility of the isolate with the insecticides (Table 5). There are still few works of selectivity of insecticides based on etofenprox to M. anisopliae, hence these evaluations are important. Gassen et al. (2008) evidenced the compatibility of thiamethoxam with B.bassiana indicating their use in an integrated pest management program. It is noteworthy that in vitro tests optimally expose the fungus to the phytosanitary product. However, this does not occur in field conditions, where external factors such as solar radiation, drift and winds act directly on the product, and alter the action of the active principle on the fungus (Cavalcanti et al., 2002).

According to Azevedo and Pizzirani-Kleiner (2002), the contact of the fungus with certain phytosanitary products, during a certain period or development phase, allowed the entomopathogen to produce viable conidia, suggesting that the microorganism recovers before a source of stress. This demonstrates the adaptive capacity in relation to the environment.

Through the method of spraying, the entomopathogen was found to be compatible with the fungus. These results can be related to the germination of the fungus, which can be initiated when the conditions of the medium are favorable for vegetative growth. However, some lineages have the characteristic of germinating in unfavorable conditions (Fregonesi et al., 2016). Thus, this is a possible explanation for the good results obtained using this methodology.

From these results, it is possible that insecticides which showed positive results of compatibility in the spray methodology, can be applied in agriculture without altering the natural development of entomopathogens. This is because the toxicity of an in vitro product does not always indicate its toxicity in the field, but rather the possibility of a toxic effect (Moino \& Alves, 1998); after all, laboratory conditions do not accurately reflect the natural field conditions (Mochi et al., 2005).

It is important to point out that, in general, the application of insecticides to the fungi B. bassiana and M. anisopliae, by incorporation method, was more toxic. This is as a result of the fact that when fungal germination begins, the hypha comes into contact with the product thereby reducing mycelial growth and sporulation.

In relation to the fungicides tested on B. bassiana and M.anisopliae, inhibition was observed regarding the active ingredients used. When the fungicide was incorporated into the culture medium, all treatments prevented mycelial growth, consequently, the sporulation of entomopathogens (Tables 2 and 3).

The tricyclazole fungicide did not completely affect mycelial growth and sporulation of the B. bassiana isolates, allowing an average growth of $12.19 \mathrm{~mm}$ and sporulation of $18.21 \%$, differing significantly from the control. Tamai et al. (2002) tested fungicides based on B. bassiana and confirmed the toxicity of some chemical groups evaluated in this work as strobilurin and triazole, which were very toxic to the fungus.

In the application of fungicides by spraying, M. anisopliae had mycelial growth in all treatments, but the only one that did not differ significantly from the control was tricyclazole, with $47.58 \mathrm{~mm}$ of growth which also did not differ from the control in the sporulation, with $70.2 \%$ of conidia production, the other products did not record indices of sporulation. Similar results for tricyclazole and azoxystrobin were observed for M. anisopliae by Rampelotti-Ferreira et al. (2010).

According to the test biological toxicity index (IB), B. bassiana and M. anisopliae obtained the same classification for all fungicides, regardless of the method used, and the treatments were considered toxic for the isolates according to the criterion adopted, except for tricyclazole which was classified as compatible when sprayed (Tables 4 and 5).

There is great difficulty in the classification of a pesticide as selective or harmful to entomopathogens, it depends on a series of variables to be considered, as standardizetion for each crop, in an attempt to make this characteristic of the pesticides (selectivity) be considered when choosing the best product for use in the crop. 
Recent research has shown that a large part of the farmers $(60.8 \%)$ did not know some natural enemies of the pests located on their farms. The knowledge of the natural enemies of the pests is an indirect indicator that leads to ecologically sustainable behaviors in the choice of pesticides. That is why this knowledge must be brought to the producer (Sharifzadeh et al., 2018).

The results obtained in this work are promising, since the evaluation of the selectivity to biological control agents is of great importance in the present day. The inadequate use of pesticides in large crops causes a loss of efficiency on the biological target, directly affecting these organisms that are present in nature, playing a role as natural pest biocontrollers.

\section{Conclusions}

Flubendiamide is very toxic to B. bassiana and M. anisopliae, producing $100 \%$ inhibition when incorporated into the medium, demonstrating that it is not selective to the fungus. However, when sprayed under $M$. anisopliae it shows compatibility.

Chlorantraniliprole end spinosad was compatible with B. bassiana and M. anisopliae, under the two methods of contact, incorporation and spraying.

Etofenprox and thiamethoxam have been shown to be moderately compatible with B. bassiana. Etofenprox is compatible with $M$. anisopliae mainly by the method of spraying under the fungus.

Of the fungicides tested, tricyclazole was the only one that showed compatibility with fungi by the spray method.

\section{Acknowledgements}

This study was financed in part by the Coordenação de Aperfeiçoamento de Pessoal de Nível Superior-Brasil (CAPES)-Finance Code 001. To Universidade Federal de Pelotas (UFPel), for granting the Master's. And to Prof $^{a}$ Cândida Renata Jacobsen de Farias, Dr. Ana Paula Schneid Afonso da Rosa and Renata Moccellin for all guidance during these two years.

\section{References}

Agrofit. (2016). Ministério da Agricultura, Pecuária e Abastecimento. Retrieved May 15, 2016, from http://www.agricultura.gov.br/servicos-e-sistemas/sistemas/agrofi

Alves, S. B., Moino, Jr. A., Almeida, J. E. M. (1998) Produtos fitossanitários e entomopatógenos. In S. B. Alves (Ed.), Controle microbiano de insetos (pp. 217-238). Piracicaba, FEALQ. https://doi.org/10.1590/S0103-90 161999000100029

Azevedo, J. L. de, \& Pizzirani-Kleiner, A. A. (2002). Melhoramento de fungos de importância na agricultura. In I. S. de Melo, M. C. Valadares-Inglis, L. L. Nass, \& A. C. C. Valois (Eds.), Recursos genéticos e melhoramento-microrganismo (pp. 323-355). Jaguariúna, Embrapa Meio Ambiente.

Barbosa, P., Hines, J., Kaplan, I., Martinson, H., Szczepaniec, A., \& Szendrei, Z. (2009). Associational resistance and associational susceptibility: having right or wrong neighbors. Annual Review of Ecology and Systematics, 40, 1-20. https://doi.org/10.1146/annurev.ecolsys.110308.120242

Bettiol, W. (2011). Biopesticide use and research in Brazil. Outlooks on Pest Management, 6(22), 280-283. https://doi.org/10.1564/22dec10

Botelho, A. A. A., \& Monteiro, A. C. (2011). Sensibilidade de fungos entomopatogênicos a agroquímicos usados no manejo da cana-de-açúcar. Bragantia, 2(70), 361-369. https://doi.org/10.1590/S0006-87052011000 200016

Carbone, I., \& Kohn, L. M. (1999). A method for designing primer sets for speciation studies in filamentous ascomycetes. Mycologia, 91, 553-556. https://doi.org/10.2307/3761358

Carlile, M. J., Watkinson, S. C., \& Gooday, G. W. (2001). The Fungi (2nd ed., p. 578). London: Academic Press. https://doi.org/10.1016/B978-012738445-0/50020-4

Cavalcanti, R. S., Moino, Jr. A., Souza, G. C., \& Arnosti, A. (2002). Efeito dos produtos fitossanitários fenpropatrina, imidacloprid, iprodione e tiametoxam sobre o desenvolvimento do fungo Beauveria bassiana (Bals.) Vuill. Arquivos do Instituto Biológico, 3(69), 17-22.

Chávez, B. Y., Rojas, J. C., Barrera, J. F. E., \& Gómez, J. (2016). Avaliação da patogenicidade de Beauveria bassiana sobre Pachycoris torridus no Laboratorio. Entomologista do Sudoeste, 3(41), 783-790. https://doi.org/10.3958/059.041.0320 
Galm, U., \& Sparks, T. C. (2015). Natural product derived insecticides: Discovery and development of spinetoram. Journal of Industrial Microbiology and Biotechnology, 43, 185-193. https://doi.org/10.1007/ s10295-015-1710-X

Gassen, M. H., Batista Filho, A., Zappelini, L. O., \& Wenzel, I. M. (2008). Efeito de agrotóxicos utilizados na cultura da goiaba sobre o fungo entomopatogênico Beauveria bassiana (Bals.) Vuill. Arquivos do instituto Biológico, 3(75), 327-342.

El-Wakeil, N., Gaafar, N., Sallam, A., \& Volkmar, C. (2013). Side effects of insecticides on natural enemies and possibility of their integration in plant protection strategies. In S. Trdan (Ed.), Insecticides-Development of Safer and More Effective Technologies (pp. 3-56). Intech.

Dalzoto, P. R., \& Uhry, K. F. (2009). Controle biológico de pragas no Brasil por meio de Beauveria bassiana (Bals.) Vuill. Arquivos do Instituto Biológico, 71, 37-41.

Fonseca, A. P. P., Marques, E. J., Torres, J. B., Silva, L. M., \& Siqueira, H. A. (2015). Lethal and sublethal effects of lufenuron on sugarcane borer Diatraea flavipennella and its parasitoid Cotesia flavipes. Ecotoxicology, 9(24), 1869-1879. https://doi.org/10.1007/s10646-015-1523-8

Fregonesi, A. F., Mochi, D. A., \& Monteiro, A. C. (2016). Compatibilidade de isolados de Beauveria bassiana a inseticidas, herbicidas e maturadores em condições de laboratório. Arquivos do Instituto Biológico, 83, 01-08. https://doi.org/10.1590/1808-1657000242014

Ghini, R., \& Kimati, H. (2000). Resistência de fungos a fungicidas. Embrapa Meio Ambiente, 78. Retrieved from https://www.alice.cnptia.embrapa.br/handle/doc/13231

Mochi, D. A., Monteiro, A. C., \& Barbosa, A. C. (2005). Action of pesticides to Metarhizium anisopliae in soil. Neotropical Entomology, 6(34), 961-971. https://doi.org/10.1590/S1519-566X2005000600013

Moino, Jr. A., \& Alves, S. B. (1998). Efeito de Imidacloprid e Fipronil sobre Beauveria bassiana (Bals.) Vuill. e Metarhizium anisopliae (Metsch.) Sorok. e no comportamento de limpeza de Heterotermes tenuis (Hagen). Anais da Sociedade Entomológica do Brasil, 27, 611-619. https://doi.org/10.1590/S0301-80591998000 400014

Moro, L.B., Polanczyk, R. A., Pratissoli, D., Carvalho, J. R., \& Franco, C. R. (2011). Potencial do uso de fungos entomopatogênicos no controle de Tetranychus urticae Kock (Acari: Tetranychidae) em mamoeiro: efeito de cultivares sobre a patogenicidade. Arquivos do Instituto Biológico, 78, 267-272.

Neves, P. M. O. J., Hirose, E., Tchujo, P. T., \& Moino, Jr. A. (2001). Compatibility of Entomopathogenic Fungi with neonicotinoid insecticides. Neotropical Entomology, 30, 263-268. https://doi.org/10.1590/S1519-566X 2001000200009

Paiva-Guimarães, A. G. L., Freire, K. R. L., Santos, S. F. M., Almeida, A. F., \& Sousa, A. C. B. (2019). Alternative substrates for conidiogenesis of the entomopathogenic fungus Beauveria bassiana (Bals) Vuill em in (Deuteromycotina: Hyphomycetes). Brazilian Journal of Biology. https://doi.org/10.1590/1519-6984. 195711

Pires, L. M., Marques, E. J., De Oliveira, J. V., \& Alves. S. B. (2010). Seleção de isolados de fungos entomopatogênicos para o controle de Tuta absoluta (Meyrick) (Lepidoptera: Gelechiidae) e sua compatibilidade com alguns inseticidas usados na cultura do tomateiro. Neutropical Entomology, 39, 977-984. https://doi.org/10.1590/S1519-566X2010000600020

Rampelotti-Ferreira, F. T., Ferreira, A., Prando, H. F., Tcacenco, F. A., Grützmacher, A. D., \& Martins, J. F. Da S. (2010). Seletividade de agrotóxicos utilizados na cultura do arroz irrigado ao fungo Metarhizium anisopliae, agente de controle microbiano de Tibraca limbativentris. Ciência Rural, 4(40), 745-751. https://doi.org/10.1590/S0103-84782010005000062

Reis, E. M., Reis, A. C., \& Zanatta, M. (2018). Reflexo econômico e desenvolvimento da resistência de Phakopsora pachyrhizi a fungicidas em função do número de aplicações. Summa Phytopathologica, 3(44), 289-292. https://doi.org/10.1590/0100-5405/176382

Rossi-Zalaf, L. S., Alves, S. B., Lopes, R. B., Silveira, Neto. S., \& Tanzini, M. R. (2008). Interação de microrganismos com outros agentes de controle de pragas e doenças. In S. B. Alves, \& R. B. Lopes (Eds.), Controle microbiano de pragas na América Latina: Avanços e desafios (pp. 270-302). Piracicaba: FEALQ. 
Sharifzadeh, M., Abdollahzadeh, G., Damalas, C. C., \& Rezaei, R. (2018). Farmer's criteria for pesticide selection and use in the pest control process. Agriculture, 8(2), 24. https://doi.org/10.3390/agriculture 8020024

Silva, G. M. H., Ferreira, G. F., Bezerra, N. S., Tavares, L. M., Almeida, A. F., \& Sousa, A. C. B. (2018). Produção de Amilase e Protease Obtidas por Metarhizium Anisopliae Var. Anisopliae Através da Fermentação em Estado Sólido. Revista Saúde e Ciência online, 7(2), 502.

Sindieveg. (2016). Setor de agroquímicos confirma queda nas vendas em 2016. News Online. Retrieved from $\mathrm{http}: / /$ sindiveg.org.br/sindiveg-news

Sitta, R. B., Gouveia, L., \& Sosa-Gomez, D. R. (2009). Compatibilidade de inseticidas com fungos entomopatogênicos. Jornada Acadêmica da Embrapa Soja, 4 (Embrapa Soja. Documento, 312). Londrina: Editado por Odilon Ferreira Saraiva, Pula Geron Saiz Melo. Retrieved from https://ainfo.cnptia.embrapa.br/ digital/bitstream/item/72358/1/ID-29937pdf

Soares, F. B., \& Monteiro, A. C. (2011). Compatibilidade de Metarhizium anisopliae com carrapaticidas químicos. Arquivos do Instituto Biológico, 3(78), 385-391.

Svedese, V. M., Lima, E. A. L. A. L., \& Porto, A. L. F. (2013). Horizontal Transmission and Effect of the Temperature in Pathogenicity of Beauveria bassiana Against Diatraea saccharalis (Lepidoptera: Crambidae). Brazilian Archives of Biology and Technology, 3(56), 413-419. https://doi.org/10.1590/ S1516-89132013000300009

Tamai, M. A., Alves, S. B., Lopes, R. B., Faion, M., \& Padulla, L. F. L. (2002). Toxicidade de produtos fitossanitários para Beauveria bassiana (Bals.) Vuill. Arquivos do Instituto Biológico, 3(69), 89-96.

Thilagam, P., Sivasubramanian, P., Kuttalam, S., \& Kubendran, G. (2010). Compatibility of Flubendiamide 480 SC (Fame) against Trichoderma viride (Persoon) and Beauveria bassiana (Balsamo). Pestology, 34, 53-55.

White, T. J., Bruns, T., Lee, S., \& Taylor, J. (1990). Amplification and direct sequencing of fungal ribosomal RNA genes for phylogenetics. In M. A. Innis, D. H. Gelfand, J. J. Sninsky, \& T. J. White (Eds.), PCR Protocols: A Guide to Methods and Applications (pp. 315-322). Academic Press. San Diego. https://doi.org/ 10.1016/B978-0-12-372180-8.50042-1

\section{Copyrights}

Copyright for this article is retained by the author(s), with first publication rights granted to the journal.

This is an open-access article distributed under the terms and conditions of the Creative Commons Attribution license (http://creativecommons.org/licenses/by/4.0/). 